\title{
Multiple Pathways of Apoptosis Induced by Roscovitine in Leukemic Cell Lines In Vitro
}

\author{
Hairong Song ${ }^{1}, \AA_{k}$ ke Sidén ${ }^{2}$ and Zuzana Hassan ${ }^{*}, 1,3$
}

\author{
${ }^{I}$ Experimental Cancer Medicine, Clinical Research Center, Department of Laboratory Medicine, ${ }^{2}$ Department of \\ Neurology, ${ }^{3}$ Center for allogeneic stem cell transplantation, Karolinska University Hospital, Huddinge, 14186, Stock- \\ holm, Sweden
}

\begin{abstract}
Roscovitine is a potent inhibitor of cyclin-dependent kinases (CDKs) that competes with the ATP binding pocket of kinases. Roscovitine has been shown to have cytotoxic effect on cancer cell lines in vitro and also in tumor xenografts in vivo. A strong synergistic effect in combination with conventional cytostatics has been reported in cancer cell lines in vitro. In this study, the mechanisms of roscovitine- induced cell death were investigated in human leukemic cell lines HL-60, Jurkat and K562. Cells were incubated with roscovitine $(0.5-200 \mu \mathrm{mol} / \mathrm{L})$ up to 24 hours and cell viability and proliferation were studied using resazurin and ${ }^{3} \mathrm{H}$-thymidine incorporation assays, respectively. Cell cycle and mitochondrial membrane potential were analyzed using flow cytometry, apoptosis was assessed using morphological criteria in Giemsa staining and apoptotic pathways using Western blot analysis. Both viability and proliferation were inhibited in a concentration-dependent manner in all cell lines. Estimated $\mathrm{IC}_{50}$ was 17, 24 and $47 \mu \mathrm{mol} / \mathrm{L}$ for HL-60, Jurkat and K562, respectively. Loss of mitochondrial membrane potential, release of cytochrome c, active fragment of caspase- 3 and cleaved PARP were observed in all three cell lines. The cleaved fragments of caspase- 2 and -8 were observed in HL-60 and Jurkat cells and the order of appearance differed between these two cell lines, while none of these fragments was observed in K562 cells. Thus, roscovitine is a potent inducer of apoptosis in leukemic cells and apoptosis has been mediated through different pathways depending on the cell line.
\end{abstract}

Keywords: Roscovitine, CDKI, apoptosis, cell cycle, leukemia.

\section{INTRODUCTION}

Cell cycle aberration and apoptosis dysregulation are the hallmark of human cancer [1]. Cyclin-dependent kinases (CDKs) are critical regulators of cell cycle progression and cellular transcription, but they are also associated with apoptosis. CDKs have been suggested to be an attractive target for development of novel anticancer drugs [2]. Roscovitine is a 2,6,9- trisubstituted aminopurine analogue that competes with ATP for binding to the active site on CDKs. It strongly inhibits CDK2/cyclin E, CDK7/cyclin $\mathrm{H}$ and CDK9/cyclin T $[3,4]$. It also inhibits rRNA processing, RNA polymerase II transcription, MDM2 expression, $\mathrm{Rb}$ phosphorylation and causes DNA damage. Roscovitine can induce apoptosis in p53-dependent or p53-independent manner [5-11]. Several studies have shown that roscovitine has cytotoxic effect on a broad range of tumor cell lines in vitro, and have the ability to suppress human colon and uterine cancer xenografts in vivo [12]. Synergistic effect of roscovitine with conventional cytostatic drugs such as gemcitabine, doxorubicine and cisplatin have been found [13-15].

The primary cause of chemotherapy failure in leukemia is resistant disease due to defects in cell cycle regulation or apoptotic pathways [16]. Chronic myeloid leukemia (CML) is probably the most extensively studied human malignancy. It is characterized by the BCR/ABL fusion gene that is related to resistance to cytostatic drugs [17]. Recently, it has been found that roscovitine or its analogues flavopiridol and

*Address correspondence to this author at the Experimental Cancer Medicine, Clinical Research Center, Novum, Karolinska University Hospital Huddinge, 14186 Stockholm, Sweden; Tel: +46-8-58583856; Fax: +46-858583850; E-mail: Zuzana.Hassan@ki.se olomoucine induce apoptosis in leukemic cells in vitro when combined with different proteasome or signal pathway inhibitors in vitro [18-22]. Thus, roscovitine in combination with other drugs may be the future therapeutic strategy in leukemia.

In our study, we investigated the effect of CDK-inhibitor roscovitine on human leukemia cells. Our results demonstrated that roscovitine rapidly induced apoptosis through activation of caspase- 2 or -8 associated with mitochondrial injury in HL-60 and Jurkat cell lines, respectively, while in K562 cells, apoptosis was initiated through the mitochondrial pathway.

\section{MATERIALS AND METHODS}

\section{Reagents}

The following materials were used: RPMI 1640 medium, Dulbecco's phosphate-buffer saline (PBS), fetal bovine serum (FBS) (Gibco, Invitrogen, Stockholm, Sweden), roscovitine (LC laboratories, Boston, USA), etoposide (BristolMyers Squibb, Bromma, Sweden), ${ }^{3} \mathrm{H}$-Thymidine (Amersham Pharmacia Biotech AB, Uppsala Sweden), resazurin (R\&D systems Inc, Minneapolis, MN, USA), propidium iodide (PI) and ribonuclease A (RNase A) (Sigma-Aldrich Sweden AB, Stockholm Sweden), ethanol (Kemety1, Haninge, Sweden).

\section{Cell Cultures}

The HL-60 cell line was purchased from DSMZ (Braunschweig, Germany), Jurkat and K562 were purchased from ATCC (LGC Promochem AB, Boras, Sweden). Cells were grown in PRMI 1640 medium supplemented with $10 \%$ 
heat-inactivated FBS (complete medium) at $37^{\circ} \mathrm{C}$ in $95 \%$ humidified $5 \% \mathrm{CO}_{2}$ atmosphere. Cells were seeded at a concentration of $2 \times 10^{5}$ cells $/ \mathrm{ml}$. All experiments were run in exponentially growing cells in complete medium without antibiotics.

\section{Treatment}

The stock solution of roscovitine in a concentration of 50 $\mathrm{mmol} / \mathrm{L}$ was prepared in DMSO and stored at $-20^{\circ} \mathrm{C}$. Stock solution was diluted in culture medium immediately before use. Cells were incubated with roscovitine in final concentrations of $0.5,1,5,10,25,50,100$ and $200 \mu \mathrm{mol} / \mathrm{L}$ up to $24 \mathrm{~h}$. The cells treated with etoposide (VP16) in a final concentration of $6 \mu \mathrm{g} / \mathrm{ml}$ for $24 \mathrm{~h}$ served as a positive control for apoptosis. The final concentration of DMSO in all experiments was $0.2 \%$. The cells grown in complete medium served as controls.

\section{Viability and Proliferation}

Cell viability was studied using resazurin viability assay. Ten thousands cells were seeded in triplicates on 96 wells black microplates and incubated with roscovitine for 24 and $72 \mathrm{~h}$. Then resazurin was added to each well in a final concentration of $10 \%$ and incubated for $2 \mathrm{~h}$ at $37^{\circ} \mathrm{C}$. Fluorescence was read using Fluostar Optima (BMG Labtech, Offenburg, Germany) at a wavelength $590 \mathrm{~nm}$.

Proliferation was assessed using ${ }^{3} \mathrm{H}$-thymidine incorporation assay. Aliquots of $0.2 \mathrm{ml}$ of cell suspension were incubated in triplicates in 96 wells microplates with $1 \mu \mathrm{Ci}^{3} \mathrm{H}$ thymidine for $4 \mathrm{~h}$ at $37^{\circ} \mathrm{C}$. The activity was measured using scintillation fluid (Optiscint Hisafe, Amersham Pharmacia Biotech AB, Uppsala Sweden) and scintillation counter (WALLAC, EG\&G Comp, Turku, Finland).

\section{Cell Cycle Analysis}

The cells were washed once in PBS, fixed in $70 \%$ ethanol in PBS and stored at $-20^{\circ} \mathrm{C}$ until analysis. Then the cells were washed in cold PBS, stained in hypotonic PI solution $(20 \mu \mathrm{g} / \mathrm{ml})$ and incubated with RNase A (100 $\mu \mathrm{g} / \mathrm{ml})$ for 30 minutes. The DNA profile was analyzed using FACScan flow cytometer and CELL Quest software (Becton Dickinson, San Jose, CA, USA).

\section{Assessment of Apoptosis}

Apoptotic cells were identified with morphological criteria such as condensed chromatin and fragmented nuclei in May-Grünwald-Giemsa staining on cytospin slides. Apoptosis was estimated as percentage of a minimum of 400 counted cells per slide.

\section{Assessment of Mitochondrial Membrane Permeability}

Mitochondrial membrane permeability $(\Delta \Psi \mathrm{m})$ was assessed using tetramethylrhodamine methyl ester (TMRM, Molecular Probes, Carlsbad, California, USA), which specifically accumulates into mitochondria depending on $\Delta \Psi \mathrm{m}$. Cells treated with roscovitine and controls were incubated with TMRM in a final concentration of $25 \mathrm{nmol} / \mathrm{L}$ at $37^{\circ} \mathrm{C}$ for $30 \mathrm{~min}$. After washing, the cells were resuspended in 1 $\mathrm{ml}$ of PBS, and analyzed using flow cytometry.

\section{Western Blot Analysis}

Cells were lysed in lysis buffer $(50 \mathrm{mmol} / \mathrm{L}$ Tris $\mathrm{pH} 7.4$, Complete mini protease inhibitor cocktail, $0.1 \mathrm{~mol} / \mathrm{L}$ PMSF, TritonX 100) on ice for $30 \mathrm{~min}$. The lysate was then centrifuged at $10000 \mathrm{~g}$ for $5 \mathrm{~min}$ at $4^{\circ} \mathrm{C}$, and stored at $-70^{\circ} \mathrm{C}$. The subcellular fractions were prepared as follows: The cells were suspended in buffer $(5 \mathrm{mmol} / \mathrm{L}$ Tris- $\mathrm{HCl}, \mathrm{pH} 7.4,5$ $\mathrm{mmol} / \mathrm{L}$ succinate acid, $10 \mathrm{mmol} / \mathrm{L} \mathrm{MgCl}_{2}, 0.5 \mathrm{mmol} / \mathrm{L}$ EDTA, $147.5 \mathrm{mmol} / \mathrm{L} \mathrm{KCl}, 5 \mathrm{mmol} / \mathrm{L} \mathrm{KH}_{2} \mathrm{PO}_{4}, 0.005 \%$ digitonin), and incubated on ice for $10 \mathrm{~min}$, and then centrifuged at $10000 \mathrm{~g}$ for $5 \mathrm{~min}$ at $4^{\circ} \mathrm{C}$. Supernatant containing cytosolic fraction was collected. The remaining pellet was resuspended in Complete mini protease inhibitor cocktail and stored at $-70^{\circ} \mathrm{C}$.

Protein concentrations were determined with BCA protein assay (Pierce, Rockford, IL, USA) according to the manufacturer's recommendations. Protein samples $(20 \mu \mathrm{g})$ were separated with $12 \%$ SDS-PAGE and transferred to a PVDF membrane. The PVDF membrane was blocked in $5 \%$ non-fatty dry milk solution at $4^{\circ} \mathrm{C}$ overnight and then incubated with primary antibodies for $2 \mathrm{~h}$ at room temperature. The following primary antibodies were used: rabbit antibodies against caspase-2, -3, -8, Bid, Bcl- $\mathrm{X}_{\mathrm{L}}$ (Becton Dickinson, Stockholm, Sweden) and actin (Sigma, St. Louis, MO, USA), and mouse antibodies against cytochrome c (Becton Dickinson, Stockholm, Sweden), Bcl-2 (Dako Sweden AB, Stockholm, Sweden) and PARP (Oncogene Research Products, Boston, MA, USA). The dilution of primary antibodies was 1:5000 (except for actin and PARP 1:1000). After washing, the membrane was incubated with a peroxidaseconjugated secondary anti-rabbit or anti-mouse antibody in dilution 1:10000 (except for actin and PARP 1:2000) for $1 \mathrm{~h}$ at room temperature. The proteins were visualized using ECL Plus Western Blotting Detection Reagents (Amersham Pharmacia Biotech AB, Uppsala Sweden).

\section{Statistical Analysis}

All quantitative experiments were performed three times. Results are expressed as mean \pm SD.

\section{RESULTS}

\section{Effect of Roscovitine on Cell Viability and Proliferation}

Roscovitine decreased viability of all cell lines in a concentration-dependent manner (Fig. 1). Different sensitivities to roscovitine were observed with $\mathrm{IC}_{50}$ of 17,24 and 47 $\mu \mathrm{mol} / \mathrm{L}$ in HL-60, Jurkat and K562, respectively. Maximum effect of roscovitine was reached within $24 \mathrm{~h}$ of incubation and prolonged exposure to roscovitine for $72 \mathrm{~h}$ did not further increase cytotoxicity in any of the cell lines. The cytotoxic effect was irreversible, since decrease in viability remained unchanged when the cells were incubated with roscovitine for $24 \mathrm{~h}$, then washed and incubated in roscovitine-free media up to $72 \mathrm{~h}$ (data not shown). Incubation with DMSO in the final concentration of $0.2 \%$ did not affect viability of cells.

Proliferation decreased in a concentration- and timedependent way in all cell lines (Fig. 2). However, the effect was most pronounced in HL-60 cells. 


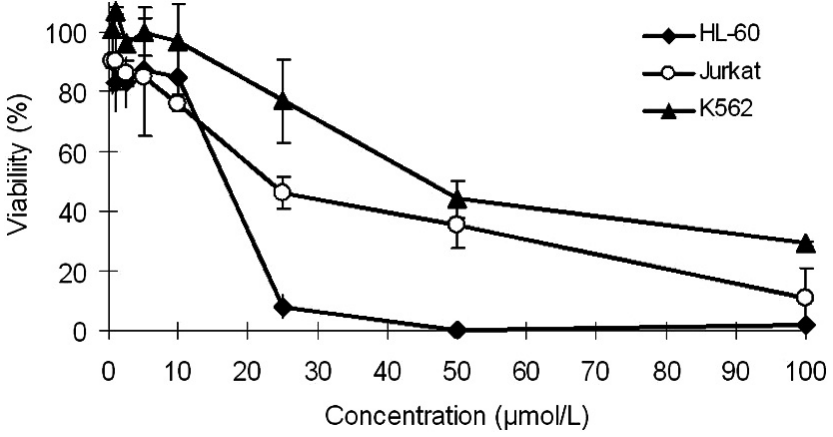

Fig. (1). The effect of roscovitine on viability of HL-60, Jurkat and K562 cell lines. Cells were seeded in a concentration of 10000 cells per well in triplicates and exposed to roscovitine in concentrations of 0.5 to $100 \mu \mathrm{mol} / \mathrm{L}$ for $24 \mathrm{~h}$. Viability was assessed using resazurin assay. Cells incubated with complete medium served as controls. The results were calculated as a percentage of the appropriate control. Experiments were run three times and results are expressed as mean $\pm \mathrm{SD}$.

\section{Roscovitine-Induced Apoptosis and Cell Cycle Analysis}

Roscovitine induced apoptosis in a concentration- and time-dependent manner in all three cell lines. Roscovitine in concentrations of 25 and $50 \mu \mathrm{mol} / \mathrm{L}$ induced apoptosis in HL-60 and Jurkat cells. Apoptotic morphology was observed already at $3 \mathrm{~h}$ and was markedly increased at $6 \mathrm{~h}$ of the treatment with roscovitine (Fig. 3a,b). In K562 cell line, apoptotic morphology was induced by concentrations of 100 $\mu \mathrm{mol} / \mathrm{Land} 200 \mu \mathrm{mol} / \mathrm{L}$ (Fig. 3c).

Roscovitine induced apoptosis without preceding phase arrest at $6 \mathrm{~h}$ and $24 \mathrm{~h}$ in HL-60 and Jurkat cells. The maximum sub-G1 peak was detected at $24 \mathrm{~h}$ (Fig. 4a,b), simultaneously with morphological changes. However, in K562 roscovitine in a concentration of $50 \mu \mathrm{mol} / \mathrm{L}$ arrested the cells at $\mathrm{G} 2 / \mathrm{M}$, while a concentration of $200 \mu \mathrm{mol} / \mathrm{L}$ resulted in the sub-G1 population increase (Fig. 4c).

\section{Mitochondrial Membrane Potential}

Loss of $\Delta \Psi \mathrm{m}$ was concentration- and time-dependent (Fig. 5). A marked loss of $\Delta \Psi \mathrm{m}$ was observed already after exposure to roscovitine in concentrations of 25 and 50 $\mu \mathrm{mol} / \mathrm{L}$ for $2 \mathrm{~h}$ in Jurkat and HL-60 cell lines. Roscovitine in a concentration of $5 \mu \mathrm{mol} / \mathrm{L}$ did not induce a loss of $\Delta \Psi \mathrm{m}$ in Jurkat or HL-60 cells (data not shown). In K562, a marked loss of $\Delta \Psi \mathrm{m}$ was firstly observed after exposure to roscovitine in concentrations of 100 and $200 \mu \mathrm{mol} / \mathrm{L}$ for $24 \mathrm{~h}$. Only slight loss of $\Delta \Psi \mathrm{m}$ was observed after incubation with roscovitine in a concentration of $50 \mu \mathrm{mol} / \mathrm{L}$ for $24 \mathrm{~h}$, lower concentrations ( 5 and $25 \mu \mathrm{mol} / \mathrm{L}$ ) did not affect $\Delta \Psi \mathrm{m}$ (data not shown). DMSO exposure did not affect $\Delta \Psi \mathrm{m}$ compared to control group in any of the cell lines. Thus, the mitochondrial pathway is involved in roscovitine-induced apoptosis.

\section{Effect of Roscovitine on Apoptotic Pathways}

In HL-60, initiator caspase- 2 was cleaved to $15 \mathrm{kDa}$ fragment and caspase- 8 to $23 \mathrm{kDa}$ fragment already at $6 \mathrm{~h}$. The effector caspase-3 was cleaved to $17 \mathrm{kDa}$ fragment. PolyADP-ribose polymerase (PARP) was cleaved to 85 kDA, thus confirming caspase-3 activation. Fragment of (a)

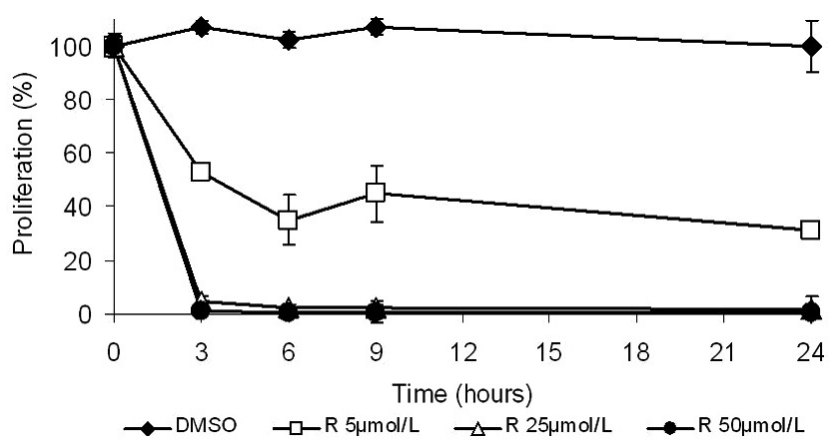

(b)

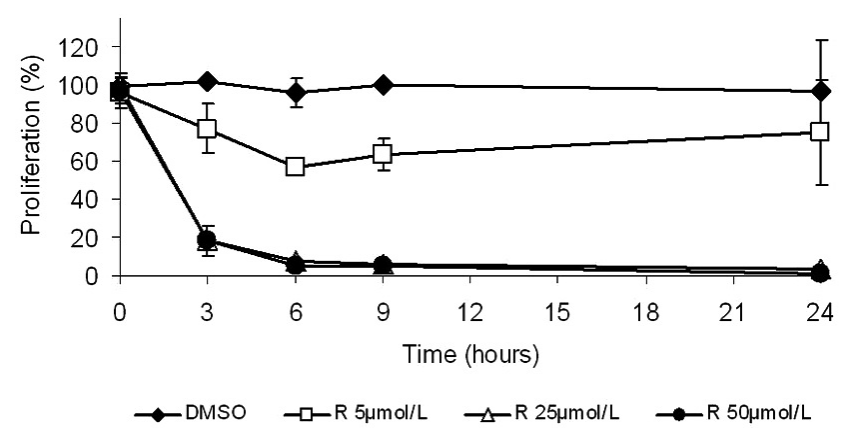

(c)

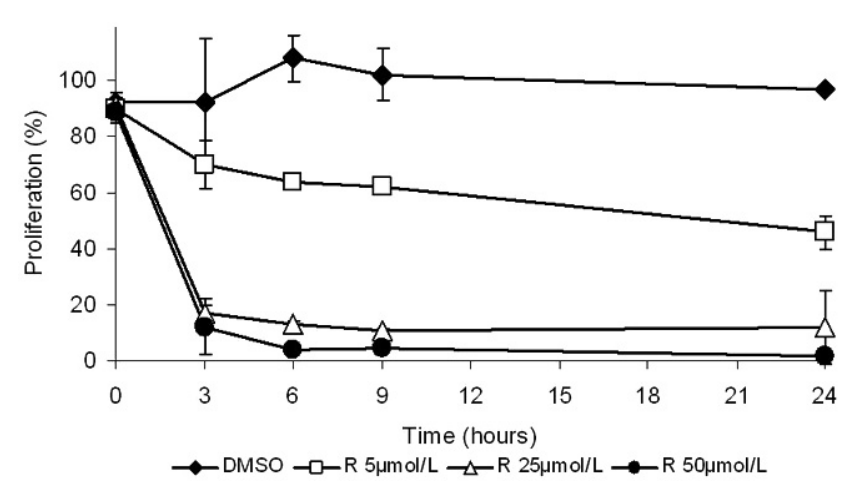

Fig. (2). The effect of roscovitine on cell proliferation. Cells were treated with roscovitine in concentrations of 5 to $50 \mu \mathrm{mol} / \mathrm{L}$ up to $24 \mathrm{~h}$. Cells treated with DMSO in a final concentration of $0.2 \%$ served as a control for solvent toxicity, while cells incubated with complete medium served as a control. Aliquot of $0.2 \mathrm{ml}$ were seeded in 96 wells plate in triplicated and proliferation was assessed using the ${ }^{3} \mathrm{H}$-thymidine incorporation assay. Proliferation was calculated as a percentage of the control. All experiments were run three times. Results are expressed as means \pm SD. (a) HL-60 cell line; (b) Jurkat cell line; and (c) K562 cell line.

Bcl-2 of $23 \mathrm{kDa}$ was found together with cytochrome-c release and tBid translocation to mitochondrial compartment. In Jurkat cells, the cleavage of caspase- 8 preceded cleavage of caspase-2. Full-length $\mathrm{Bcl}-\mathrm{X}_{\mathrm{L}}$ disappeared, while $\mathrm{Bcl}-2$ remained intact. Also in Jurkat cell line, the active fragment of caspase-3, together with PARP cleavage, cytochrome-c release and tBid translocation were observed (Fig. 6a,b). 
(a)

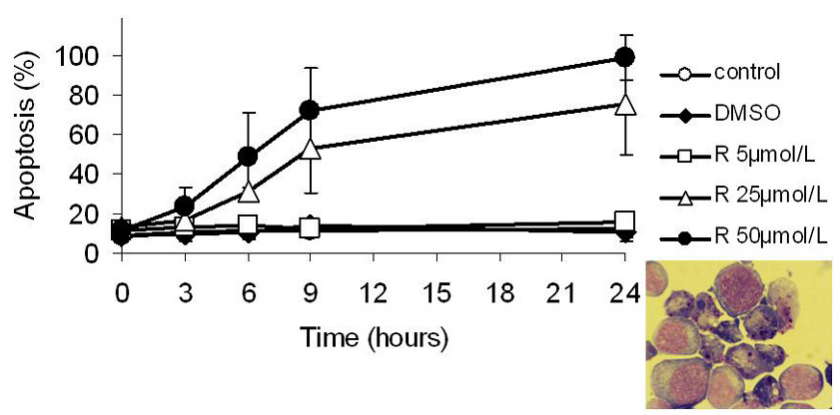

(b)

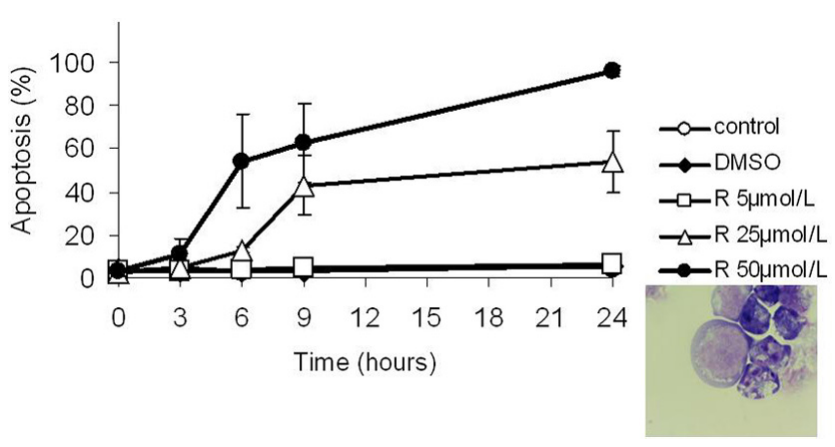

(c)

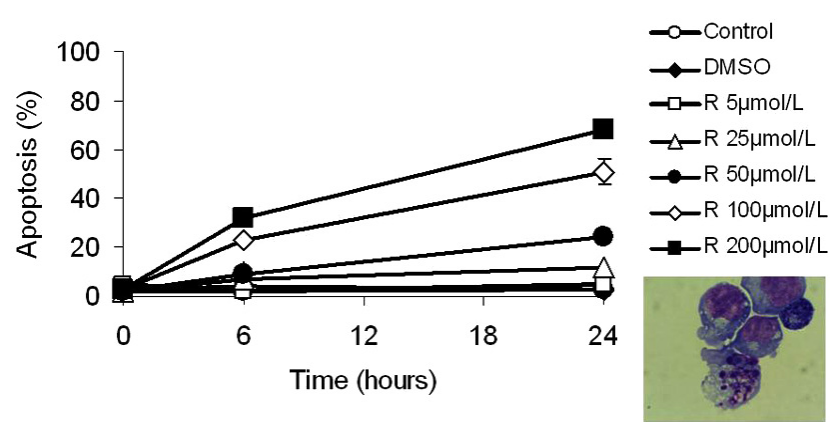

Fig. (3). Roscovitine-induced apoptosis. Cells were incubated with roscovitine in concentrations of 25 to $200 \mu \mathrm{mol} / \mathrm{L}$ up to $24 \mathrm{~h}$. DMSO in final a concentration of $0.2 \%$ served as a control for solvent toxicity, while cells incubated with complete medium served as a control. Apoptosis was assessed using morphological criteria in minimum of 400 cells on cytospined slides in Giemsa staining. All experiments were run three times. Results are expressed as means \pm SD. The images represent the intact and apoptotic cells of appropriate cell line. (a) HL-60 cell line; (b) Jurkat cell line; and (c) K562 cell line.

Neither caspase-8, nor caspase-2 was cleaved in K562 cells treated with roscovitine in concentrations of 100 $\mu \mathrm{mol} / \mathrm{L}$ and $200 \mu \mathrm{mol} / \mathrm{L}$ for $24 \mathrm{~h}$. Caspase- 3 cleavage was observed at $24 \mathrm{~h}$ incubation with 100 and $200 \mu \mathrm{mol} / \mathrm{L}$ roscovitine. Full length $\mathrm{Bcl}-\mathrm{X}_{\mathrm{L}}$ protein disappeared after the treatment with roscovitine for $24 \mathrm{~h}$ implicating the cleavage of the protein simultaneously with cytochrome-c release (Fig. 6c). No such effects were observed after incubation with roscovitine in a concentration of $50 \mu \mathrm{mol} / \mathrm{L}$ (data not shown). Actin remained intact in all three cell lines treated with roscovitine. (a)

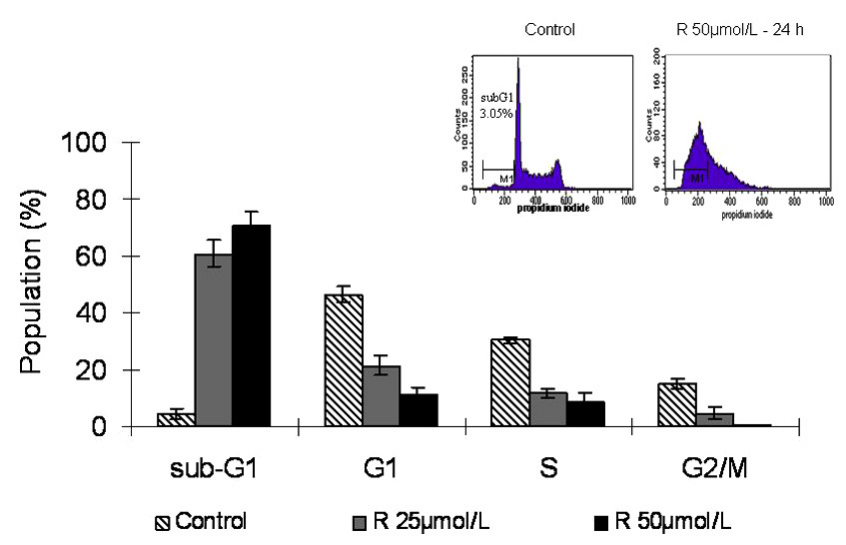

(b)

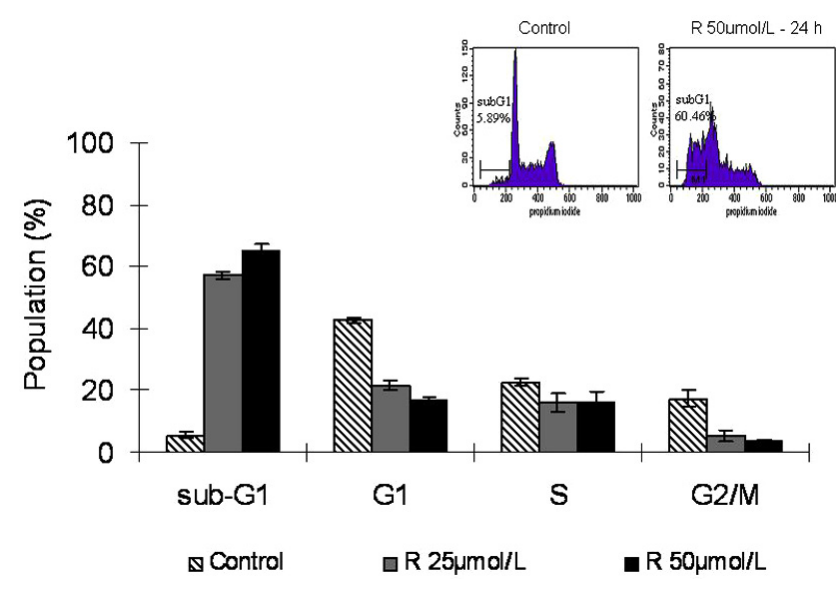

(c)

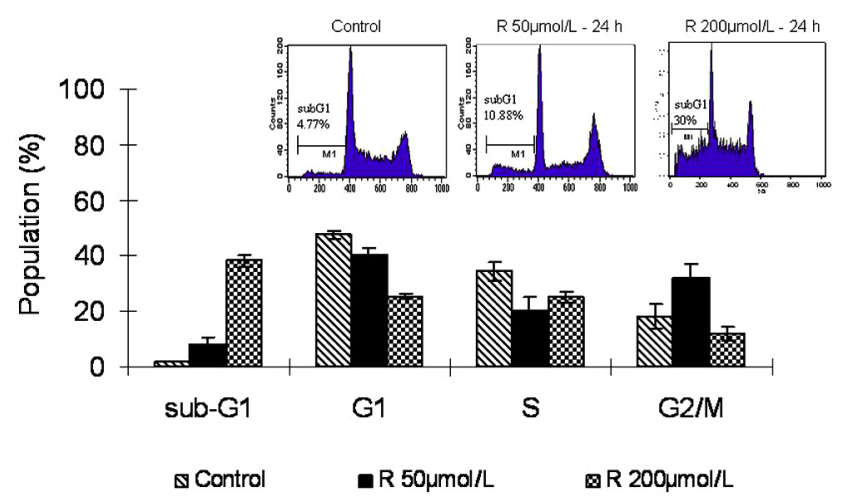

Fig. (4). Effect of roscovitine on cell cycle. Cells were incubated with roscovitine in concentrations of 5 to $200 \mu \mathrm{mol} / \mathrm{L}$ for $24 \mathrm{~h}$. Cells incubated with complete medium served as a control. Following incubation, the cells were washed in PBS, fixed in 70\% ethanol and stained with propidium iodide. The DNA profile was analyzed using flow cytometry. All experiments were run three times. Results are expressed as means \pm SD. (a) HL-60 cell line; (b) Jurkat cell line; and (c) K562 cell line.

\section{DISCUSSION}

Roscovitine is a potent CDK inhibitor that has been developed as a targeted anticancer drug. It has been shown to induce apoptosis in several cancer cell lines in vitro and in 


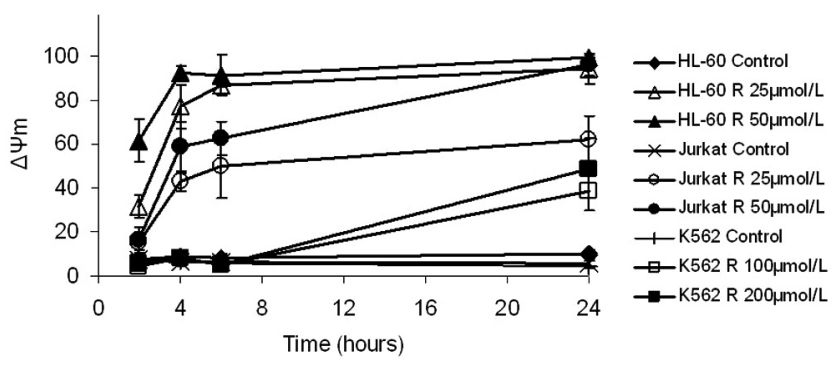

Fig. (5). Effect of roscovitine on loss of mitochondrial membrane potential. Cells were incubated with roscovitine in concentrations of 25 to $200 \mu \mathrm{mol} / \mathrm{L}$ up to $24 \mathrm{~h}$. Cells treated with DMSO in a final concentration of $0.2 \%$ served as a control for solvent toxicity, while cells incubated with complete medium served as a control. Loss of $\Delta \Psi \mathrm{m}$ was assessed using TMRM assay and flow cytometry. All experiments were run three times. Results are expressed as means \pm SD.

xenograft models in vivo. In our study, we investigated the cytotoxic effect of roscovitine on leukemic cell lines of different origin, myeloid HL-60, lymphoblastic Jurkat and CML K562 cells. The $\mathrm{IC}_{50}$ of $17 \mu \mathrm{mol} / \mathrm{L}, 24 \mu \mathrm{mol} / \mathrm{L}$ and 47 $\mu \mathrm{mol} / \mathrm{L}$ were observed in HL-60, Jurkat and K562 cells, respectively (Fig. 1). The $\mathrm{IC}_{50}$ observed in HL-60 and Jurkat cells were similar to published data. The average $\mathrm{IC}_{50}$ of 15 $\mu \mathrm{mol} / \mathrm{L}$ (range $5-36 \mu \mathrm{mol} / \mathrm{L}$ ) was reported in cancer cell lines $[4,14,15,23,24]$, but the $\mathrm{IC}_{50}$ of $\mathrm{K} 562$ cells was higher. Roscovitine decreased the DNA synthesis in all three leukemic cell lines (Fig. 2). This inhibitory effect of roscovitine in vitro is in line with data reported for human gliomas, cervical cancer, as well as embryonic lung fibroblasts $[10,25,26]$. Two mechanisms probably are involved in the effect. Firstly, roscovitine was found to cause DNA damage via DNA double strand breaks (DSBs), to downregulate DNA-PK activity and NHEJ pathway, and to reduce DNA replication proteins such as proliferating cell nuclear antigen during S-phase [7, 27, 28]. Secondly, inhibition of S- phase $\mathrm{CDK} 2 /$ cyclin $\mathrm{A}$ activity and ERK1/2 kinases are related to the effect of roscovitine on DNA synthesis [1, 8]. Roscovitine inhibits $\mathrm{CDK} 7$ and $\mathrm{CDK}$ 9, that results in decreased expression of cyclins D1, A and B1 and decreased DNA synthesis in the S-phase [29]. Roscovitine has been reported to induce apoptosis preceded by either a G1/S or a G2/M cell cycle arrest in many cell lines [12]. In our experiment, apoptosis was induced without a prior cell cycle arrest in HL-60 and Jurkat cells (Fig. 4). In both HL-60 and Jurkat cell lines, p53 was either not detected or not functional [28, 30]. However, apoptosis was induced early during the incubation with roscovitine in our study in HL-60 and Jurkat cell lines (Fig. 3), which may implicate that roscovitine could have therapeutic potential to overcome resistance related to p53 mutations in tumors.

In K562 cell line derived from patient suffering from blastic crisis of CML, low concentrations of roscovitine did not affect the cell viability or proliferation (Figs. 1,3). However, a G2/M phase arrest was observed after the treatment with roscovitine in a concentration of $50 \mu \mathrm{mol} / \mathrm{L}$ (Fig. 4c). Usually, BCR/ABL positive cells display prominent G2/M delay, and prolonged repair of DSBs to evade apoptosis [29]. However, after incubation with roscovitine in a concentration of $200 \mu \mathrm{mol} / \mathrm{L}$, abrogation of G2 checkpoint arrest oc- curred with an increased number of sub-G1 cells (Fig. 4c). Loss of p53 function leading to inappropriate mitotic entry was reported in K562 cells [29]. Our data suggest that roscovitine in a concentration of $200 \mu \mathrm{mol} / \mathrm{L}$ is able to induce p53-independent apoptosis as cells fail to sustain the prolonged G2/M phase.

In HL-60 and Jurkat cell lines, roscovitine was a potent inhibitor of cell viability and proliferation, and caused rapid induction of apoptosis. Cleavage of caspases and loss of mitochondrial function during apoptosis were observed concurrently (Figs. 5,6). Caspase-2 has been implicated as an inducer caspase in DNA damage, and high levels procaspase-2 were associated with very poor survival in AML [31]. Our study is the first to demonstrate that caspase-2 plays an important role in roscovitine-induced apoptosis in leukemic cells, but the mechanism of caspase-2-induced apoptosis remains unknown [32]. The active caspase- 8 was observed in HL-60 and Jurkat cells. In both HL-60 and Jurkat cells, tBid was detected by Western blot analysis after exposure to roscovitine (Fig. 6a,b). It has been suggested that caspase-2, -8 , and granzyme-B cleave Bid at different site of Asp in DNA damage pathway [27]. Cleaved caspase3 contributes, as an effector caspase, to the morphological and functional changes in apoptosis, and is also responsible for the inactivation of the PARP processed during the later stages of apoptosis [33].

Another mechanism of apoptotic regulation is via the mitochondrion. Its dysfunction including the loss of $\Delta \Psi \mathrm{m}$, permeability transition and release of cytochrome $\mathrm{c}$ into cytosol induces apoptosis [34]. Disruption of $\Delta \Psi \mathrm{m}$ has been shown at $2 \mathrm{~h}$ of exposure to roscovitine in HL-60 and Jurkat cells (Fig. 5), indicating the involvement of the mitochondrial pathway in roscovitine-induced death. Cytochrome c was released in roscovitine-treated Jurkat and HL-60 cells (Fig. 6a,b). In turn, cytochrome c binds to Apaf 1, resulting in the recruitment and activation of caspase- 9 which directly cleaves pro-caspase-3 and -7 [33]. Bcl-2 family regulates the permeability of the mitochondrial outer membrane. Bcl-2 and $\mathrm{Bcl}-\mathrm{X}_{\mathrm{L}}$ are members of the anti-apoptotic group which are cleaved in HL-60 and Jurkat cells treated with roscovitine (Fig. 6). Overexpression of $\mathrm{Bcl}-2$ or $\mathrm{Bcl}-\mathrm{X}_{\mathrm{L}}$ protein have been associated with drug resistance in hematological malignancies [34], since they exert their inhibitory effect on apoptosis by blocking the release of cytochrome $\mathrm{c}$ and mitochondrial $\Delta \Psi \mathrm{m}$ [35]. Downregulation of the function of antiapoptotic proteins is a method to overcome this resistance. Roscovitine synergistically interacted with $\mathrm{Bcl}-2 / \mathrm{Bcl}-\mathrm{X}_{\mathrm{L}}$ antagonist and induced apoptosis in leukemia cells (U937, HL-60 and Jurkat) [21]. In K562 cells, oncogene BCR/ABL encodes a constitutively active form of ABL tyrosine kinase. Substrates of BCR/ABL kinase include Ras, PI3K/Akt and Src family kinase that play an important role in signaling pathways regulating cell survival and death. Moreover, BCR/ABL kinase activates STAT5, and thus contributes to transcriptional activation of $\mathrm{Bcl}-\mathrm{X}_{\mathrm{L}}$ resulting in inhibiton of apoptosis [36,37]. We treated the cells with roscovitine in concentrations of 100 and $200 \mu \mathrm{mol} / \mathrm{L}$ for $24 \mathrm{~h}$. Loss of fulllength $\mathrm{Bcl}-\mathrm{X}_{\mathrm{L}}$ together with loss of $\Delta \Psi \mathrm{m}$, cytochrome $\mathrm{c}$ and cleavage of caspase-3 were observed (Figs. 5,6c), but caspase-2 and -8 remained intact. This indicates that roscovitine-induced apoptosis in $\mathrm{K} 562$ cells is related to mito- 
(a)
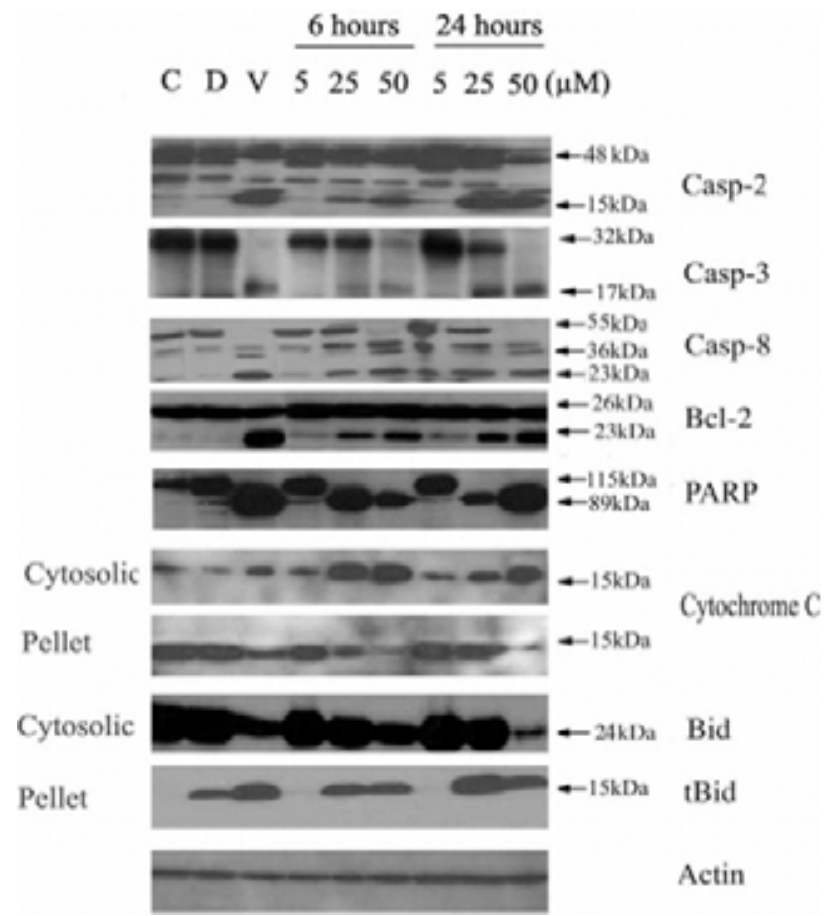

(b)
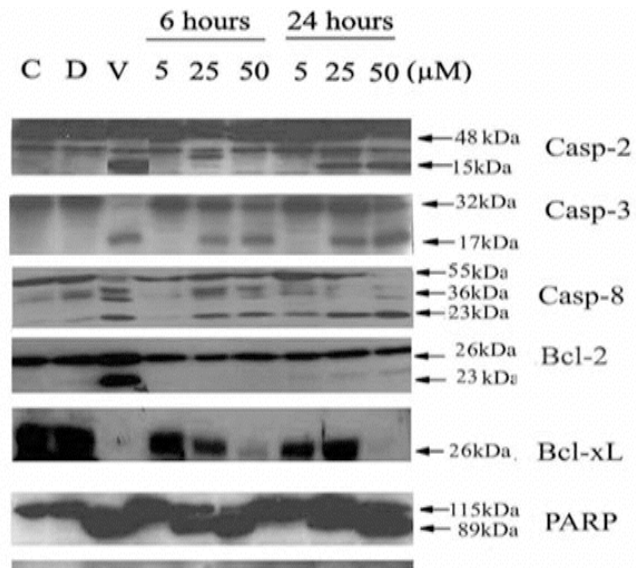

Pellet

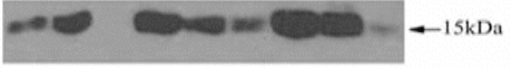

Cytosolic

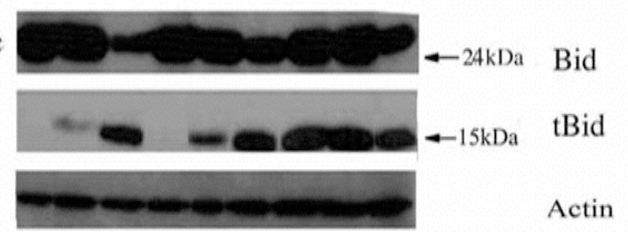

(c)

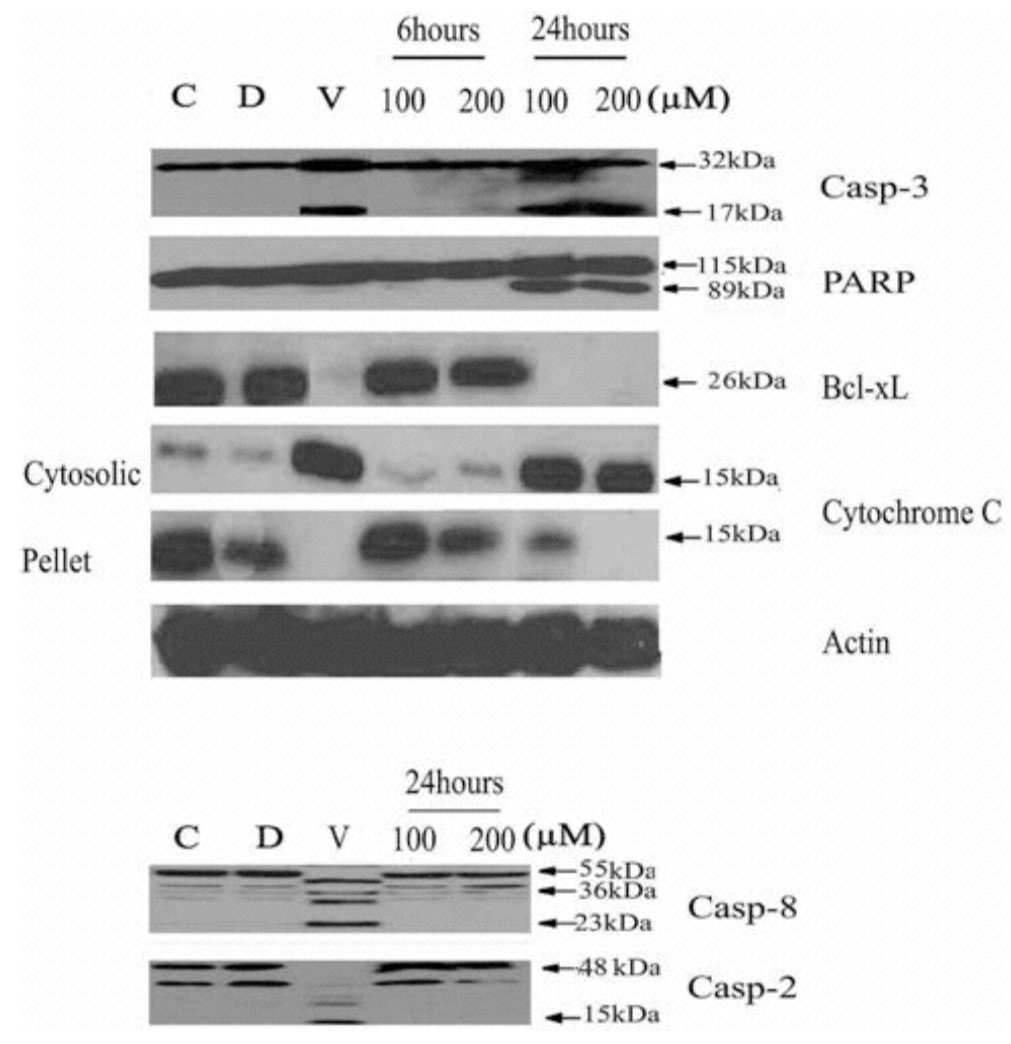

Fig. (6). Protein analysis in roscovitine-induced apoptosis. Cells were incubated with roscovitine in concentrations of 5 to $200 \mu$ mol/L for 6 and $24 \mathrm{~h}$. Cells treated with DMSO in a final concentration of $0.2 \%$ served as a control for solvent toxicity (D), while cells incubated with complete medium served as a control (C). Cells incubated with etoposide (V) in a final concentration of $6 \mu \mathrm{g} / \mathrm{ml}$ for $24 \mathrm{~h}$ served as a positive control for apoptosis. Level of expression and/or integrity of proteins were investigated by immunoblotting. Blots were subsequently stripped and probed with antibody directed against actin to ensure equivalent loading and transfer. (a) HL-60 cell line; (b) Jurkat cell line; and (c) K562 cell line. 
chondrial pathway. It has been reported that PI3K/Akt signaling pathway rather than MEK1/2/MAPK, plays a major role in regulating the apoptotic response of human leukemic cells (U937, CCRF, NB4, HL-60 and Jurkat) to CDK inhibitors roscovitine and flavopiridol [20]. However, no study reported the mechanisms of roscovitine induced apoptosis in K562 cells.

In summary, roscovitine exerts its cytotoxicity by inducing mitochondrial injury, caspase activation, and apoptosis in human leukemia cells, however, the kinetics of the events differs depending on the cell type. CDKI might pave a new way of the treatment of CML for which ABL tyrosine kinase is generally a therapeutic target.

\section{ACKNOWLEDGEMENTS}

This study was supported by grants from the Children's Cancer Foundation (PROJ04/085, PROJ04/098, PROJ06/ 121) and postdoc grant for Zuzana Hassan from Karolinska University Hospital.

\section{REFERENCES}

[1] Schwartz, G.K.; Shah, M.A. J. Clin. Oncol., 2005, 23, 9408-21.

[2] Shapiro, G.I. J. Clin. Oncol., 2006, 24, 1770-83.

[3] Alessi, F.; Quarta, S.; Savio, M.; Riva, F.; Rossi, L.; Stivala, L.A.; Scovassi, A.I.; Meijer, L.; Prosperi, E. Exp. Cell Res., 1998, 245, 818.

[4] McClue, S.J.; Blake, D.; Clarke, R.; Cowan, A.; Cummings, L.; Fischer, P.M.; MacKenzie, M.; Melville, J.; Stewart, K.; Wang, S.; Zhelev, N.; Zheleva, D.; Lane, D.P. Int. J. Cancer, 2002, 102, 4638.

[5] Hahntow, I.N.; Schneller, F.; Oelsner, M.; Weick, K.; Ringshausen, I.; Fend, F.; Peschel, C.; Decker, T. Leukemia, 2004, 18, 747-55.

[6] Lu, W.; Chen, L.; Peng, Y.; Chen, J. Oncogene, 2001, 20, 3206-16.

[7] Maggiorella, L.; Deutsch, E.; Frascogna, V.; Chavaudra, N.; Jeanson, L.; Milliat, F.; Eschwege, F.; Bourhis, J. Cancer Res., 2003, 63, 2513-7.

[8] Vitali, L.; Yakisich, J.S.; Vita, M. F.; Fernandez, A.; Settembrini, L.; Siden, A.; Cruz, M.; Carminatti, H.; Casas, O.; Idoyaga Vargas, V. Cancer Lett., 2002, 180, 7-12.

[9] Ljungman, M.; Paulsen, M.T. Mol. Pharmacol., 2001, 60, 785-9.

[10] Whittaker, S.R.; Walton, M.I.; Garrett, M.D.; Workman, P. Cancer Res., 2004, 64, 262-72.

[11] Alvi, A.J.; Austen, B.; Weston, V.J.; Fegan, C.; MacCallum, D.; Gianella-Borradori, A.; Lane, D.P.; Hubank, M.; Powell, J.E.; Wei, W.; Taylor, A.M.; Moss, P.A.; Stankovic, T. Blood, 2005, 105, 4484-91.

[12] Tirado, O.M.; Mateo-Lozano, S.; Notario, V. Cancer Res., 2005, 65, 9320-7.

[13] Crescenzi, E.; Palumbo, G.; Brady, H.J. Clin. Cancer Res., 2005, $11,8158-71$.
[14] Raje, N.; Kumar, S.; Hideshima, T.; Roccaro, A.; Ishitsuka, K.; Yasui, H.; Shiraishi, N.; Chauhan, D.; Munshi, N.C.; Green, S.R.; Anderson, K.C. Blood, 2005, 106, 1042-7.

[15] MacCallum, D. E.; Melville, J.; Frame, S.; Watt, K.; Anderson, S.; Gianella-Borradori, A.; Lane, D.P.; Green, S.R. Cancer Res., 2005, 65, 5399-407.

[16] Schimmer, A.D.; Hedley, D.W.; Penn, L.Z.; Minden, M.D. Blood, 2001, 98, 3541-53.

[17] Deininger, M.; Buchdunger, E.; Druker, B.J. Blood, 2005, 105, 2640-53.

[18] Dai, Y.; Rahmani, M.; Grant, S. Oncogene, 2003, 22, 7108-22.

[19] Rosato, R.R.; Almenara, J.A.; Maggio, S.C.; Atadja, P.; Craig, R.; Vrana, J.; Dent, P.; Grant, S. Mol. Cancer Ther., 2005, 4, 1772-85.

[20] Yu, C.; Rahmani, M.; Dai, Y.; Conrad, D.; Krystal, G.; Dent, P.; Grant, S. Cancer Res., 2003, 63, 1822-33.

[21] Chen, S.; Dai, Y.; Harada, H.; Dent, P.; Grant, S. Cancer Res. 2007, 67, 782-91.

[22] Edamatsu, H.; Gau, C.L.; Nemoto, T.; Guo, L.; Tamanoi, F. Oncogene, 2000, 19, 3059-68.

[23] Lacrima, K.; Rinaldi, A.; Vignati, S.; Martin, V.; Tibiletti, M.G.; Gaidano, G.; Catapano, C.V.; Bertoni, F. Leuk. Lymphoma, 2007, 48, 158-67.

[24] Mohapatra, S.; Chu, B.; Zhao, X.; Pledger, W.J. Cancer Res., 2005 65, 7717-23.

[25] Savio, M.; Cerri, M.; Cazzalini, O.; Perucca, P.; Stivala, L.A.; Pichierri, P.; Franchitto, A.; Meijer, L.; Prosperi, E. Cell Cycle, 2006, 5, 2153-9.

[26] Yakisich, J.S.; Boethius, J.; Lindblom, I.O.; Wallstedt, L.; Vargas, V.I.; Siden, A.; Cruz, M.H. Neuroreport, 1999, 10, 2563-7.

[27] Abal, M.; Bras-Goncalves, R.; Judde, J.G.; Fsihi, H.; De Cremoux, P.; Louvard, D.; Magdelenat, H.; Robine, S.; Poupon, M.F. Oncogene, 2004, 23, 1737-44.

[28] Werner, A.B.; Tait, S.W.; de Vries, E.; Eldering, E.; Borst, J. J. Biol. Chem., 2004, 279, 28771-80.

[29] Skorski, T. Oncogene, 2002, 21, 8591-604.

[30] Niida, H.; Nakanishi, M. Mutagenesis, 2006, 21, 3-9.

[31] Estrov, Z.; Thall, P.F.; Talpaz, M.; Estey, E.H.; Kantarjian, H.M.; Andreeff, M.; Harris, D.; Van, Q.; Walterscheid, M.; Kornblau, S.M. Blood, 1998, 92, 3090-7.

[32] Guo, Y.; Srinivasula, S.M.; Druilhe, A.; Fernandes-Alnemri, T.; Alnemri, E.S. J. Biol. Chem., 2002, 277, 13430-7.

[33] Rodriguez-Hernandez, A.; Brea-Calvo, G.; Fernandez-Ayala, D.J.; Cordero, M.; Navas, P.; Sanchez-Alcazar, J.A. Apoptosis, 2006, 11, 131-9.

[34] Del Poeta, G.; Venditti, A.; Del Principe, M.I.; Maurillo, L.; Buccisano, F.; Tamburini, A.; Cox, M.C.; Franchi, A.; Bruno, A.; Mazzone, C.; Panetta, P.; Suppo, G.; Masi, M.; Amadori, S. Blood, 2003, 101, 2125-31.

[35] Hou, D.X.; Tong, X.; Terahara, N.; Luo, D.; Fujii, M. Arch. Biochem. Biophys., 2005, 440, 101-9.

[36] Deininger, M.W.; Goldman, J.M.; Melo, J.V. Blood, 2000, 96, 3343-56.

[37] Jabbour, E.; Cortes, J.E.; Ghanem, H.; O'Brien, S.; Kantarjian, H.M. Expert Rev. Anticancer Ther., 2008, 8, 99-110. 